\title{
Decreasing uptake of predictive testing for Huntington's disease in a German centre: 12 years' experience (1993-2004)
}

\author{
Christiane Bernhardt ${ }^{1}$, Anne-Marie Schwan ${ }^{1}$, Peter Kraus ${ }^{2}$, Joerg Thomas Epplen ${ }^{1}$ \\ and Erdmute Kunstmann*,1,3
}

\author{
${ }^{1}$ Department of Human Genetics, Ruhr-University of Bochum, Bochum, Germany; ${ }^{2}$ Department of Neurology, \\ St Josef-Hospital, Bochum, Germany; ${ }^{3}$ Department of Human Genetics, University of Wuerzburg, Wuerzburg, Germany
}

In this retrospective study, we examined changes in decision-making for and against the predictive genetic test for Huntington's disease including $\mathbf{4 7 8}$ persons at risk who had undergone genetic counselling in one centre in Germany between 1993 and 2004. At the outset of the counselling procedure the majority of subjects $(71 \%)$ wanted to make use of the test, yet the actual demand of the predictive test result declined from 67 to $38 \%$ over the years. In addition, the time interval between counselling session and blood withdrawal was reduced, as determined by the counselees: in 2000-2004 the majority of persons at risk made the appointment for blood withdrawal after the shortest possible time span. Demographic factors of the cohort remained comparatively stable in the investigated time period. An association was evident between the ratio of test usage and the counselling person. These and other possible factors influencing the time flow of predictive DNA testing are discussed. Further studies are necessary to investigate whether changes of test demand rates are a general phenomenon.

European Journal of Human Genetics (2009) 17, 295-300; doi:10.1038/ejhg.2008.164; published online 10 September 2008

Keywords: genetic testing; genetic counselling; Huntington's disease; predictive testing

\section{Introduction}

Huntington's disease (HD) is a neurodegenerative disorder characterized by movement abnormalities, psychiatric manifestations and cognitive impairment. One in 10000 individuals is affected in North-Rhine Westfalia (own unpublished data) similar to other Central European populations. ${ }^{1}$ First symptoms often occur in HD between the ages of 35 and 50 years, but onset can be earlier or later even within a given family. Average duration of the disease is between 15 and 20 years.

\footnotetext{
*Correspondence: Dr E Kunstmann, Human Genetics, University of Wuerzburg, Am Hubland, 97074 Wuerzburg, Germany.

Tel: + 49931888 4435; Fax: + 49931 45265859;

E-mail: erdmute.kunstmann@rub.de

Received 4 March 2008; revised 16 July 2008; accepted 8 August 2008; published online 10 September 2008
}

HD is inherited as an autosomal dominant trait with estimated full penetrance. In 1993, an expansion of the trinucleotide repeat (CAG) in the coding region of the Huntingtin gene $(\mathrm{Htt})$ was identified as the pathogenetic mutation. ${ }^{2}$ Alleles with 11-35 CAG repeats do not cause HD (normal but mutable alleles), whereas $\geq 40$ CAG repeats are definitively pathogenic. Repeat units 36-39 reflect HD alleles, albeit with reduced penetrance. ${ }^{3}$

Since 1993, direct DNA testing has become feasible providing definitive and thus more reliable results than indirect testing. In Germany, predictive testing is available for all persons at risk who are at least 18 years of age. Predictive testing has to be accompanied by genetic counselling according to the international guidelines. ${ }^{4}$ Clients have to undergo at least one genetic counselling and one psychological counselling session. During the initial human genetic counselling, comprehensive 
information on HD is provided. The clinical course of the disease is explained and possible consequences for important life issues are explored. In addition, various aspects of the genetic test are outlined and discussed with the counselee. At the earliest 4 weeks after the genetic counselling session blood can be drawn for DNA testing. The test result is always provided within another formal counselling session. The test applicants can abrogate, delay or interrupt the counselling/testing procedure at any step. Those counselees who wanted to have their blood taken after more than 12 months of the initial counselling appointment had an additional session to reprocess the issues of the first counselling session and to answer any actual questions. The aim of this study concerns deeper insights into the usage of predictive testing for HD and any tendencies for changes during the 12 years following the introduction of the direct DNA test.

\section{Subjects and methods}

The clients described here were counselled in Bochum, Huntington Centre of North-Rhine Westfalia from 1993 to 2004. The group consisted of 478 persons at risk in the age group of 17-72 years, mean age 35 years. The testing protocol followed the international guidelines, ${ }^{4}$ including at least two pre-test meetings (geneticist and psychologist) and one post-test counselling session.

The counsellors involved in these sessions had specialized knowledge about HD counselling and observed the international guidelines painstakingly. They had been trained to counsel in non-directive and client-centred manners. They were working in genetic counselling/ human genetics for at least 3 years and all four were females. Three counsellors were married and counsellor 2 was single. No opinions concerning the test usage were given by the counsellors. Counselees had no contact to the genetic counsellor before counselling sessions. A detailed neurological examination was not performed. Counselees received information for predictive genetic testing, in case their self-evaluation was 'healthy' with respect to HD. Patients complaining about symptoms have been excluded from this data set.

Several topics were constituents of all counselling sessions: detailed information about $\mathrm{HD}$, the genetic background of the disease and the test procedure were given, the individual risk (50 vs 25\%) was determined and communicated. Pros and cons of the test were discussed with the counselees at length. Furthermore, information was invariably provided about specialised hospital care, support groups and possible consequences of test results for obtaining insurance. Those counselees who wanted to have their blood taken after more than 12 months of the initial counselling appointment had an additional session to reprocess the issues of the first counselling session and to answer any actual questions.
DNA analyses were performed in the Genetics department by a separate investigator (Ruhr-University Bochum, Germany) through direct mutation analysis. The genetic counsellor received a closed envelope with the DNA data. The envelope was opened in front of the counselee. Hence, the counsellor was not informed about the test result before the post-test session, in which the CAG repeat length and its interpretation was disclosed to the counselee. All data were collected retrospectively from the detailed patient records starting in the second half of the year 2005. Data analyses were performed using SPSS and included descriptive statistics. Differences between the groups of different test usage were tested by $\chi^{2}$ test. Significance was defined for $P<0.05$. Approval for this study was obtained from the Ethics Committee of the Ruhr-University Bochum (Germany).

\section{Results}

The total number of persons applying for predictive testing in the Huntington Centre of North-Rhine Westfalia was 478. The sex distribution in the entire group was $43 \%$ male and $57 \%$ female. Most of the applicants (92\%) had a 50\% risk of developing HD, only $6.5 \%$ had a prior risk of 25 and $1.3 \%$ had no defined risk owing to uninformative family structure.

At the very beginning of the first counselling session counselees were asked whether they had already decided about performing the test for themselves. The majority of counselees wanted the test (73\%), whereas 13\% did not ask for testing and $14 \%$ had not had decided so far. Actually, over the whole investigated period $52 \%$ of the persons at risk finally opted for the blood withdrawal and obtained the genetic test result. The other persons at risk decided against the test or did not present for blood withdrawal and testing. Four persons at risk underwent the test, but did not make an appointment to receive their test result.

The number of healthy individuals accessing predictive counselling for $\mathrm{HD}$ as well as the percentage of persons at risk finally taking the DNA test changed over the years (Figure 1). In the years from 1993 to 1997 more than 65\% of the counselees (average 67\%) underwent DNA testing. Data analyses revealed that only few of these individuals wanted to verify test results of indirect mutation tests that had been performed previously. The percentage of test usage decreased averaging approximately 51\% in the years 1997-2000. Remarkably, from 2001 to 2004 only 33-41\% (average $38 \%$ ) of counselees decided to perform the test after the first counselling session $\left(P<0.001 ; \chi^{2}=23.9\right.$; d.f. $=2$; Figure 1$)$.

To identify possible differences between the counselees of these three periods, we analysed the demographic data of the tested and of the untested groups (Table 1). The average age was 35 years (average range $34-36$ years) in all investigated groups. Nearly all groups of test applicants showed a slight over-representation of females. Most of the counselled persons were living in a partnership, but this 


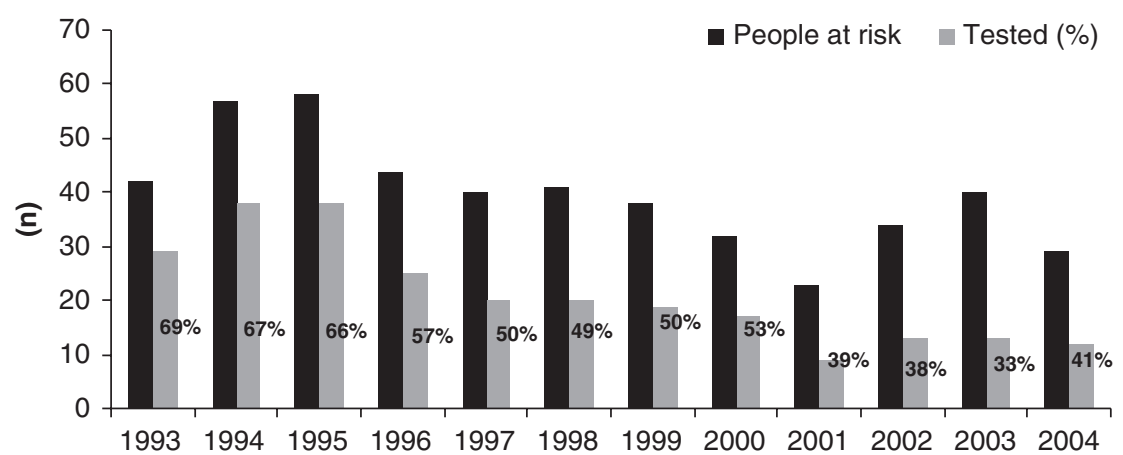

Figure 1 Number of persons at risk (black bar) and predictive test performed (grey bars) during the period 1993-2004. $\chi^{2}$ test: $P<0.001$; $\chi^{2}=23.9 ;$ d.f. $=2$.

Table 1 Demographic data for the three investigated groups $(n=478)$

\begin{tabular}{|c|c|c|c|c|c|c|}
\hline & \multicolumn{2}{|c|}{$\begin{array}{c}1993-1996 \\
n(\%)\end{array}$} & \multicolumn{2}{|c|}{$\begin{array}{c}1997-2000 \\
n(\%)\end{array}$} & \multicolumn{2}{|c|}{$\begin{array}{c}2001-2004 \\
n(\%)\end{array}$} \\
\hline & Tested & Not tested & Tested & Not tested & Tested & Not tested \\
\hline $\begin{array}{l}\text { Clients counseled } \\
\text { Average age (in years) }\end{array}$ & $\begin{array}{c}130 \\
34\end{array}$ & $\begin{array}{l}71 \\
34\end{array}$ & $\begin{array}{l}76 \\
36\end{array}$ & $\begin{array}{l}75 \\
36\end{array}$ & $\begin{array}{l}42 \\
35\end{array}$ & $\begin{array}{l}84 \\
36\end{array}$ \\
\hline $\begin{array}{l}\text { Gender } \\
\text { Female } \\
\text { Male }\end{array}$ & $\begin{array}{l}63(48) \\
67(52)\end{array}$ & $\begin{array}{l}41(58) \\
30(42)\end{array}$ & $\begin{array}{l}47(62) \\
29(38)\end{array}$ & $\begin{array}{l}46(61) \\
29(39)\end{array}$ & $\begin{array}{l}25(60) \\
17(40)\end{array}$ & $\begin{array}{l}51(61) \\
33(39)\end{array}$ \\
\hline $\begin{array}{l}\text { Marital status } \\
\text { Married/de facto } \\
\text { Separated/divorced } \\
\text { Single } \\
\text { No information }\end{array}$ & $\begin{array}{c}105(81) \\
8(6) \\
16(12) \\
1(1)\end{array}$ & $\begin{array}{c}56(79) \\
2(3) \\
10(14) \\
3(4)\end{array}$ & $\begin{aligned} 62 & (82) \\
3 & (4) \\
10 & (13) \\
1 & (1)\end{aligned}$ & $\begin{aligned} 53 & (71) \\
7 & (9) \\
11 & (15) \\
4 & (5)\end{aligned}$ & $\begin{array}{c}29(69) \\
3(7) \\
9(21) \\
1(2)\end{array}$ & $\begin{aligned} 51 & (61) \\
7 & (8) \\
18 & (21) \\
8 & (10)\end{aligned}$ \\
\hline Children before testing & $60(46)$ & $31(44)$ & $34(45)$ & $35(47)$ & $18(43)$ & $31(37)$ \\
\hline
\end{tabular}

number appears to be decreasing over the years, reflecting general population trends as shown by the Statisches Bundesamt Deutschland. Complementarily, the percentage of singles, seeking advice in HD testing matters, was highest during the period of 2001-2004 (21\% in both groups). The percentage of counselees with children was comparatively stable (average 44\%), but declined in the time 2001-2004. Over the whole time period, the number of counselees with a $25 \%$ risk asking for the test was low. The percentage varied between 4 and 14\% and did not show a certain trend in the investigated period.

Mainly four experienced genetic counsellors attended to the persons at risk in a given time span. Table 2 shows the time period of counselling for each counsellor as well as the percentage of persons at risk applying for the genetic test afterwards. Most counselees were counselled by the same counsellor (76\%) throughout the entire counselling/testing procedure. Counsellors 1 and 2 experienced the highest rates of test applications in the years 1993-1999, whereas counsellor 4 had the lowest percentage of test applicants between 2000 and $2004\left(P<0.001 ; \chi^{2}=27.8\right.$; d.f. $\left.=3\right)$. To develop hypotheses, whether involuntarily the counsellors or general attitudes changing over time influenced this parameter, additional analyses were undertaken. Over time, counsellor 1 showed a slight decrease of test application rate starting with 70\% in 1993-1996 and declining to 50\% in 1998-1999. In contrast, counsellor 2 had an average of 53\% of test applicants in 1994-1996.

At the very beginning of the first counselling session persons at risk were asked whether they had already decided to undergo genetic testing. To rule out or confirm the possible influence of the actual counsellor, we analysed this statement over the years. Results are shown in Table 3. The percentage of counselees who had decided for genetic testing in advance was relatively stable (average 71\%) across the investigated time span and varied comparatively little $(68-81 \%)$.

The time lapse between the first counselling session and the appointment of the blood withdrawal has to be at least 4 weeks according to the international guidelines. ${ }^{4}$ Irrespective of this formality, the date of the appointment for blood withdrawal is exclusively decided by the test 
Table 2 Predictive tests performed according to the four different counsellors

\begin{tabular}{lccr}
\hline Counsellor & Time period & Number of clients $(n)$ & Rate of tests performed (\%) \\
\hline Counsellor 1 & $1993-1999$ & 226 & $147(65)$ \\
Counsellor 2 & $1994-1996$ & 39 & $19(53)$ \\
Counsellor 3 & $1995-2000$ & 52 & $24(46)$ \\
Counsellor 4 & $2000-2004$ & 90 & $30(33)$ \\
\hline
\end{tabular}

$\chi^{2}$ test: $P<0.001 ; \chi^{2}=27.8 ;$ d.f. $=3$.

Table 3 Number of persons at risk decided for the test at the beginning of the counselling session during the period 1993-2004

\begin{tabular}{lcc}
\hline & Persons at risk $(n)$ & Prior decision for test (\%) \\
\hline 1993 & 42 & $29(69)$ \\
1994 & 57 & $40(70)$ \\
1995 & 58 & $47(81)$ \\
1996 & 44 & $31(70)$ \\
1997 & 40 & $27(68)$ \\
1998 & 41 & $26(63)$ \\
1999 & 38 & $30(79)$ \\
2000 & 32 & $24(75)$ \\
2001 & 23 & $18(78)$ \\
2002 & 34 & $27(79)$ \\
2003 & 40 & $28(70)$ \\
2004 & 29 & $19(66)$ \\
\hline
\end{tabular}

applicant. Figure $2 \mathrm{a}-\mathrm{c}$ describe the time period between these two appointments. We categorized the years into three groups: period 1993-1996 with the highest testing rate $(65 \%)$, period $1997-2000$ with an average testing rate (51\%) and the years from 2001 to 2004 with the lowest testing rate (38\%). Counselees having asked for their initial counselling session during 1993-1996 and 1997-2000 made their appointment for blood withdrawal within 12 months. Only a slight accumulation in the first month $(30 \%)$ is obvious. In contrast, $70 \%$ of the counselees in the period 2001-2004 presented after the shortest possible time (1 month). Few persons at risk presented for blood withdrawal after 2-15 months in this time span.

\section{Discussion}

In this study, the majority of counselees (71\%) reported intention to make use of the predictive DNA test for HD at the very beginning of the counselling session. Before direct DNA testing was available, it was reported that between 40 and $60 \%$ of people at risk reported intention to apply for the test. ${ }^{5}$ After introduction of the direct HD test much lower rates of test usage were reported. When persons at risk were approached by registries or testing centres the percentage of test applicants varied from less than $4-20 \% .^{6-8}$ In our study, counselees were not contacted by a testing centre or registry. In Germany, medical doctors (in general practice, neurologists and psychiatrists) and support groups provide information to patients and family members about HD heritability, as well as the possibility of genetic counselling and DNA testing. Despite a rather stable initial intention rate for the test over time, the actual percentage of people at risk who requested testing showed a marked decline from 1993 to 2004 (average 52\%). We are not aware of other reports on changes in test usage during the time span in question. Data from Italy during the period 1994-1996 showed that the usage of the direct test was $49 \%$ in Genova and Rome ${ }^{9}$ and thus comparatively lower than in our cohort (average 63\%) in the same time period. From the Netherlands, $80 \%$ test rate was reported in persons applying for predictive testing for HD in the years from 1987 to $1997 .^{10}$ In this latter study group the percentage of test uptake was relatively stable during the whole time period.

As stated above, our cohort shows a decrease in test usage over the years. To identify possible differences of counselees in this time period we analysed their demographic data. In our cohort, age at counselling was not a discriminating factor. Practically in all groups (except for one) there were more women than men presenting for genetic counselling. Over-representation of females undergoing predictive testing has been observed worldwide. ${ }^{11}$ Explanations for this trend include greater willingness by women to face difficult health issues and deeper involvement of females in reproduction and care of children. ${ }^{12-14}$ Moreover the data show high concordance to the demographic data of an investigated group of people at risk for HD in Australia. ${ }^{15}$ In the marital status of the counselees in our cohort there is a slight decrease in the counselees living in (longer duration) partnership in the years 2001-2004, complementarily singles presenting for predictive testing were more prevalent in recent years. In addition, the percentage of counselees having children declined. These aforementioned phenomena presumably reflect developments in the general population.

Various additional factors changing over time might influence the usage of tests for HD. Over the years, DNA testing reached more public awareness and discussion. For example, newspapers reported on a person who had to perform predictive testing for HD before being (state-) employed permanently as teacher in a public school. This episode reflects the point that gaining knowledge about apparently definable health risks may have adverse consequences on job opportunities. Possible consequences 
a 14

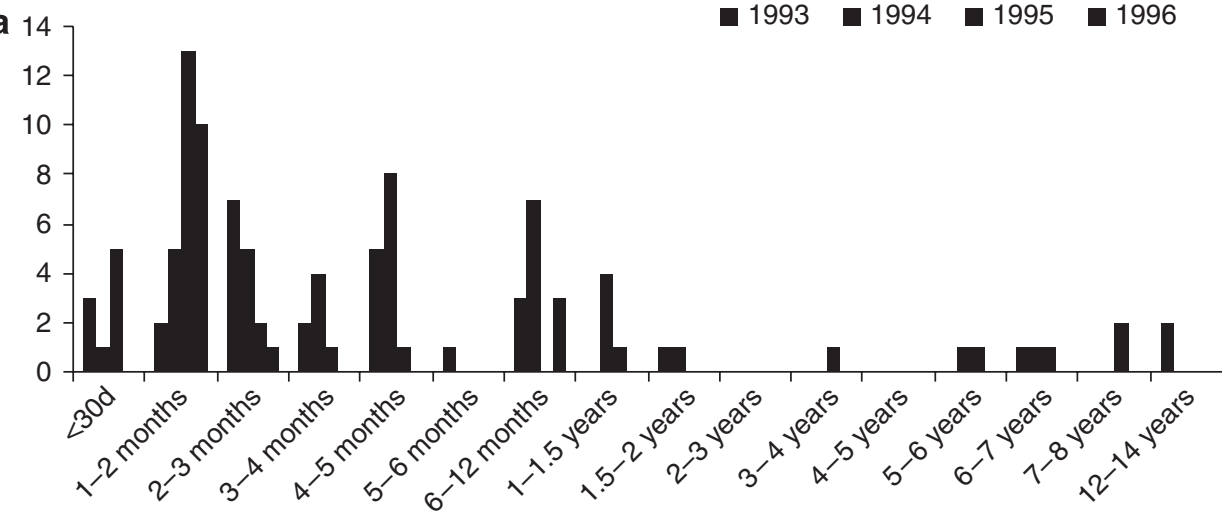

b 12
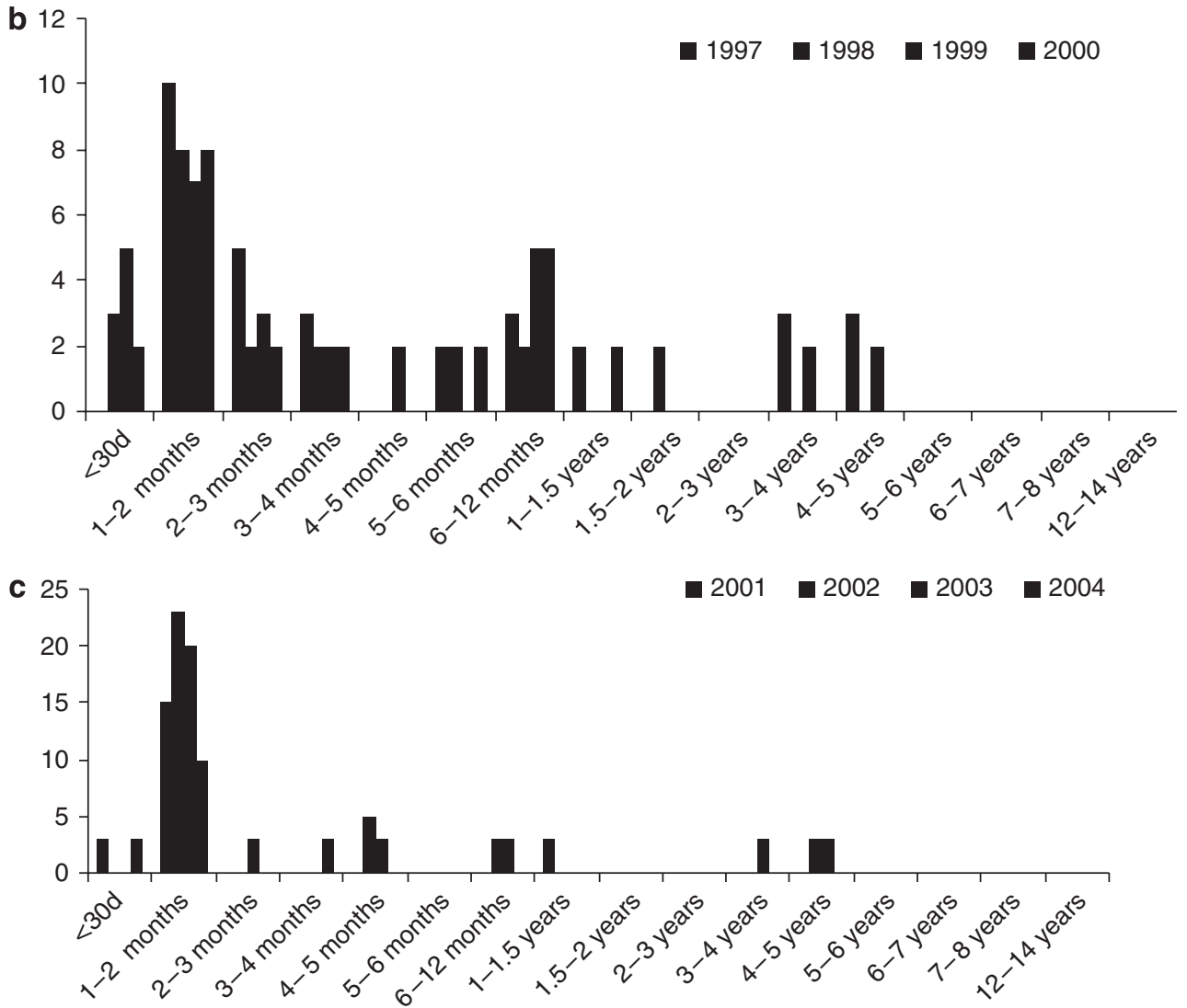

Figure 2 (a) Interval between the counselling session during the time period 1993-1996 and the blood withdrawal. (b) Interval between the counselling session during the time period 1997-2000 and the blood withdrawal. (c) Interval between the counselling session during the time period $2001-2004$ and the blood withdrawal.

were intensely discussed by human geneticists ${ }^{16}$ outlining the pros and cons of regulation by the government. Are persons at risk increasingly more aware of possible disadvantages to know about carrying the HD mutation?

The process of decision-making for predictive HD testing appears rather more complex. In the Huntington Centre of North-Rhine Westfalia there were mainly four medical doctors involved in HD counselling during 1993-2004. We correlated the individual counsellors' cases with the test usage and found varying rates from 65 to 33\%. The highest ratio of test usage was associated with counsellor 1 working from 1993 to 1999 and the lowest with counsellor 4, who was actively counselling in the years 2001-2004. The counsellors were remarkably homogenous with respect to age (30-43 years at the beginning of their HD counselling period), sex, MD education in Germany, specific prior training and supervision status. Therefore, speculations about influences may primarily relate to possible subconscious influences on the counselees' decision-making that are not analysed in this study. 
The time between counselling and blood withdrawal changed over time. The percentage of counselees presenting for blood withdrawal after the shortest possible time period was highest in 2001-2004. Taken into account that during the whole period (1993-2004) the percentage of counselees remained relatively stable in demanding the DNA test at the very beginning of the counselling session, one could suspect that the decision process of persons remaining in the test procedure may have been predetermined decisively or it might have come very rapidly to a conclusion during the later years, and the counselee presents after the shortest possible time for blood withdrawal. Influences of the counsellor in the decisionmaking process of these counselees and selection of mostly decided persons at risk could be another explanation of this aforedescribed association. In several studies factors of predictive test decision-making were scrutinised. ${ }^{17-19}$ Individuals participating in predictive testing are described as a resourceful and self-selected group. ${ }^{20}$ Test applicants were found to have relatively high ego strength/resources. ${ }^{13,21}$ The persons who did not decide to be tested seemed more frequently to tend towards inappropriate emotional reactions. ${ }^{21}$ But the influence of the counsellor has received little attention. In this context, $\operatorname{Kessler}^{22}$ critically discussed counselling skills and their consequences for effectiveness and humanity of the counselling procedure. Recently, the role of health care workers was described as being crucial gate keepers for decision-making for HD testing. ${ }^{17}$ Interaction of genetic counsellors with the decision-making processes was also demonstrated and would therefore underpin our findings. In interviews, counselees reported on feelings that counsellors were biased, warning of potential dangers of genetic knowledge. ${ }^{17}$ Irrespectively, further (prospective) studies should be designed to elucidate the complex interaction between counsellor and counselee in predictive DNA testing procedures. In addition, the need for repeated training of counsellors may be emphasised. The reasons for changing request rates for obtaining predictive DNA test results in a model disease such as HD need to be defined to optimise predictive counselling procedures in general and the counsellors' performance in each individual case. Further studies should analyse whether changes of test request rates over time is generally observed in counselling for HD and other monogenic diseases. Only such detailed knowledge on a simple model disease sets the stage to cope with the avalanche of individual problems generated in the context of predictive genetic testing.

\section{References}

1 Conneally PM: Huntington disease: genetics and epidemiology. Am J Hum Genet 1984; 36: 506-526.

2 The Huntington's Disease Collaborative Research Group: A novel gene containing a trinucleotide repeat that is expanded and unstable on Huntington's disease chromosomes. Cell 1993; 72 : 971-983.

3 Quarrell OW, Rigby AS, Barron L et al: Reduced penetrance alleles for Huntington's disease: a multi-centre direct observational study. J Med Genet 2007; 44: e68.

4 International Huntington Association and the World Federation of Neurology Research Group on Huntington's Chorea: Guidelines for the molecular genetics predictive test in Huntington's disease. J Med Genet 1994; 31: 555-559.

5 Meiser B, Dunn S: Psychological impact of genetic testing for Huntington's disease: an update of the literature. I Neurol Neurosurg Psychiatry 2000; 69: 574-578.

6 Babul R, Adam S, Kremer B et al: Attitudes toward direct predictive testing for the Huntington disease gene. Relevance for other adult-onset disorders. The Canadian Collaborative Group on Predictive Testing for Huntington Disease. JAMA 1993; 270: $2321-2325$.

7 Tibben A: Predictive testing for Huntington's disease. Brain Res Bull 2007; 72: $165-171$.

8 Laccone F, Engel U, Holinski-Feder E et al: DNA analysis of Huntington's disease: five years of experience in Germany, Austria, and Switzerland. Neurology 1999; 53: 801-806.

9 Mandich P, Jacopini G, Di Maria E et al: Predictive testing for Huntington's disease: ten years' experience in two Italian centres. Ital J Neurol Sci 1998; 19: 68-74.

10 Maat-Kievit A, Vegter-van der Vlis M, Zoeteweij M, Losekoot M, van Haeringen A, Roos R: Paradox of a better test for Huntington's disease. J Neurol Neurosurg Psychiatry 2000; 69: 579-583.

11 Goizet C, Lesca G, Durr A: Presymptomatic testing in Huntington's disease and autosomal dominant cerebellar ataxias. Neurology 2002; 59: 1330-1336.

12 Creighton S, Almqvist EW, MacGregor D et al: Predictive, prenatal and diagnostic genetic testing for Huntington's disease: the experience in Canada from 1987 to 2000. Clin Genet 2003; 63: $462-475$.

13 Decruyenaere M, Evers-Kiebooms G, Cloostermans $\mathrm{T}$ et al: Psychological distress in the 5-year period after predictive testing for Huntington's disease. Eur J Hum Genet 2003; 11: 30-38.

14 Harper PS, Lim C, Craufurd D: Ten years of presymptomatic testing for Huntington's disease: the experience of the UK Huntington's Disease Prediction Consortium. J Med Genet 2000; 37: $567-571$.

15 Richards FH, Rea G: Reproductive decision making before and after predictive testing for Huntington's disease: an Australian perspective. Clin Genet 2005; 67: 404-411.

16 Harper PS, Gevers S, de Wert G, Creighton S, Bombard Y, Hayden MR: Genetic testing and Huntington's disease: issues of employment. Lancet Neurol 2004; 3: 249-252.

17 Klitzman R, Thorne D, Williamson J, Marder K: The roles of family members, health care workers, and others in decisionmaking processes about genetic testing among individuals at risk for Huntington disease. Genet Med 2007; 9: 358-371.

18 Sarangi S, Bennert K, Howell L, Clarke A, Harper P, Gray J: (Mis)alignments in counseling for Huntington's Disease predictive testing: clients' responses to reflective frames. J Genet Couns 2005; 14: 29-42.

19 Taylor SD: Predictive genetic test decisions for Huntington's disease: context, appraisal and new moral imperatives. Soc Sci Med 2004; 58: 137-149.

20 Decruyenaere M, Evers-Kiebooms G, Boogaerts A et al: Predictive testing for Huntington's disease: risk perception, reasons for testing and psychological profile of test applicants. Genet Couns 1995; 6: 1-13.

21 Codori AM, Hanson R, Brandt J: Self-selection in predictive testing for Huntington's disease. Am J Med Genet 1994; 54: $167-173$.

22 Kessler S: Psychological aspects of genetic counseling. XIV. Nondirectiveness and counseling skills. Genet Test 2001; 5: 187-191. 